\title{
EFEK LAMA PERENDAMAN TERHADAP PERKECAMBAHAN BENIH ROSELA (Hibiscus sabdariffa L.)
}

\author{
Dede Suhendra $^{1}$,Yudi Tryanto ${ }^{2}$, Siti Hartati Yusida Saragih ${ }^{2}$,Zahlul Ikhsan ${ }^{1}$ \\ ${ }^{1}$ Program Studi Agroekoteknologi, Universitas Andalas \\ ${ }^{2}$ Program Studi Agroteknologi, Universitas Labuhanbatu \\ *Corresponding author : Desu_300392@gmail.com
}

\begin{abstract}
Rosela (Hibiscus sabdariffa L.) is a medicinal plant. Rosela has a chemical compound that can provide many benefits. Efficacy of rosella to prevent disease, treat disorders of various diseases with gossiptin anthocyanin content and gluciside hibiscin contained in it. This research was conducted at the Laboratory of College of Agricultural Sciences of Labuhan Batu University Foundation, North Sumatera Province. This research was started in March 2017. This research used Non-Factorial Randomized Block Design (RAK) with the harvesting period (P) P0: Control, P1: 1, Clock P2: 2 Hours, P3: 3 Hours P4: 4 Hours P5: 5 Hours P6: 6 Hours $P: 7$ Hours. The highest rate of germination was found in $P 7$ treatment of 3.22 days. The highest normal germination percentage was found in P5 and P7 treatment of $66.67 \%$. Than highest abnormal germination percentege was found in P3, P4 and P6 treatment of $33.33 \%$.
\end{abstract}

Keywords : Rosela, Old Immersion

\section{PENDAHULUAN}

Saat ini rosela (Hibiscus sabdariffa L.) menjadi begitu populer. Hampir di setiap pameran tanaman obat, nama rosela selalu diperkenalkan. Hal ini disebabkan hampir seluruh bagian tanaman ini dapat digunakan untuk kebutuhan pengobatan, terutama untuk pengobatan alternatif. Rosela memiliki kandungan senyawa kimia yang dapat memberikan banyak manfaat. Khasiat rosela untuk mencegah penyakit, mengobati gangguan berbagai penyakit dengan kandungan gossiptin anthocyanin dan gluciside hibiscin yang terdapat di dalamnya. Sebagaimana diketahui rosela juga mengandung berbagai senyawa penting antara lain campuran asam sitrat dan asam malat sehingga menghasilkan sedikit rasa asam yang segar. Kandungan asam askorbat (vitamin C) dan antosianin yang tinggi merupakan sumber antioksidan alami yang sangat efektif dalam menangkal berbagai radikal bebas penyebab kanker dan berbagai penyakit lainnya (Mardiah, et al., 2009).

Rendahnya vigor pada benih dapat disebabkan oleh beberapa hal, yaitu genetik, morfologis, sitologis, mekanis, mikrobia dan fisiologis. Pada kondisi fisiologis yang dapat menyebabkan rendahnya vigor benih adalah immaturity atau kurang masaknya benih saat panen dan kemunduran benih saat penyimpanan. Pada hakikatnya vigor benih harus relevan dengan tingkat produksi, artinya dari benih yang bervigor tinggi akan dapat dicapai tingkat produksi yang tinggi. Vigor benih untuk tumbuh secara spontan merupakan landasan bagi kamampuan tanaman mengabsorbsi sarana produksi secara maksimal sebelum panen juga dapat memanfaatkan unsur sinar matahari 
khususnya selama periode pengisian dan pemasakan buah (Sutopo, 1998).

Mencapai produk yang maksimum, benih yang akan ditanam harus memiliki mutu tinggi. Benih itu tidak cukup hanya memiliki kemampuan reproduksi normal pada kondisi yang optimum, tetapi juga pada kondisi yang sub optimum. Benih yang memiliki vigor kekuatan tumbuh demikian akan mampu mencapai produksi maksimum pada kondisi optimum. Benih dengan ciri diatas adalah benih dengan vigor tinggi (Sadjad, 1994).

Penggunaan benih dengan viabilitas yang sudah menurun akan meningkatkan biaya penyulaman, harga benih, mundurnya waktu tanam sehingga produksi tidak optimal dan mutunya rendah (Hasanah, 2002). Untuk mendapatkan viabilitas benih yang optimal diperlukan lama perendaman yang sesuai.

\section{Tujuan Penilitian}

Untuk mengetahui efek lama perendaman terhadap viabilitas benih rosela (Hibiscus sabdariffa L.).

\section{BAHAN DAN METODE}

Penelitian ini dilaksanakan di Laboratorium Sekolah Tinggi Ilmu Pertanian Yayasan Universitas Labuhan Batu, Provinsi Sumatera Utara. Penelitian ini mulai bulan Juni sampai Juli 2017.

Bahan yang digunakan dalam penelitian ini adalah benih rosela sebagai bahan tanaman untuk perbanyakan benih,pasir sebagai media perkecambahan. Alat - alat yang digunakan dalam penelitian ini adalah seedbak, oven, gunting, ayakan pasir, timbangan analitik, kalkulator, cangkul, gembor, tugal, sprayer, tali rafia, meteran dan alat tulis.
Rancangan yang digunakan untuk mengolah data dalam percobaan ini adalah Rancangan Acak Kelompok (RAK) faktorial dengan satu faktor yaitu dengan 8 taraf perlakuan yaitu :

Faktor pemberian Pupuk Kandang Sapi dengan 4 taraf yaitu :

$\begin{aligned} \text { P0 } & \text { : Kontrol } & \text { P4 } & \text { : 4 Jam } \\ \text { P1 } & \text { : 1 Jam } & \text { P5 } & \text { : 5 Jam } \\ \text { P2 } & \text { : 2 Jam } & \text { P6 } & \text { : 6 Jam } \\ \text { P3 } & \text { : 3 Jam } & \text { P7 } & \text { : 7 Jam } \\ & \text { Data } & \text { hasil } & \text { pengamatan }\end{aligned}$
menggunakan analisis rataan dimana terdapat nilai tertinggi dan terendah dari masing-masing perlakuan dengan menjumlahkan seluruh nilai data suatu kelompok sampel, kemudian dibagi dengan jumlah sampel tersebut.

Benih berasal lahan masyarakat di Jl. Sadikun Lestari Kelurahan Bakaran Batu, Rantauprapat. Menggunakan varietas Padang dengan mengambil buah yang sudah matang fisiologis. Kelopak buah yang telah dipanen kemudian dikupas dan biji dikeluarkan dari kelopak. Biji yang digunakan adalah biji yang ukurannya seragam, berwarna kecoklatan, tidak terserang cendawan. Media perkecambahan yang digunakan adalah media pasir dengan ketebalan $\pm 4 \mathrm{~cm}$. Sebelum digunakan terlebih dahulu pasir disterilkan dengan cara digongseng selama \pm 30 menit untuk menghilangkan kontaminasi dari cendawan dan bakteri. Pengecambahan dilakukan pada bak perkecambahan benih (seedbak) dengan ukuran $32 \mathrm{~cm}$ x 24,5 $\mathrm{cm}$ x $4 \mathrm{~cm}$ sebanyak 50 benih per seedbak. Penyiraman dilakukan pada pagi dan sore hari dengan menggunakan handsprayer hingga media menjadi lembab dan dalam kondisi kapasitas lapang.

Pengukuran parameter adalah laju perkecambahan (hari), kecambah normal 
(\%), kecambah abnormal (\%). Hasil pengamatan penelitian diketahui bahwa perlakuan lama perendaman mengamati parameter laju perkecambahan (Hari), kecambah normal (\%), kecambah abnormal (\%).

\section{HASIL DAN PEMBAHASAN}

\section{Laju Perkecambahan (hari)}

Dari hasil penelitian menunjukkan bahwa laju perkecambahan tercepat terdapat pada perlakuan P7 sebesar 3.22 hari. Lalu laju perkecambahan terlama terdapat pada perlakuan P3 sebesar 5.56 hari (Tabel 1).

Tabel 1. Rataan laju perkecambahan (hari)

\begin{tabular}{cc}
\hline Perlakuan & Laju Perkecambahan (hari) \\
\hline P1 & 4.44 \\
P2 & 4.56 \\
P3 & 5.56 \\
P4 & 5.10 \\
P5 & 4.73 \\
P6 & 3.84 \\
P7 & 3.22 \\
\hline
\end{tabular}

$\begin{array}{ccc}\text { Pada } & \text { parameter } & \text { laju } \\ \text { perkecambahan } & \text { diketahui bahwa } & \text { data }\end{array}$ tercepat terdapat pada perlakuan P7 karena semakin lama perendaman akan semakin cepat pertumbuhan nya. Perkecambahan benih juga dipengaruhi oleh lama perendaman dalam air, semakin lama perendaman maka waktu perkecambahan juga akan semakin cepat. Perlakuan benih memberikan kecepatan tumbuh yang paling baik karena air dan oksigen yang dibutuhkan dapat berkecambah, semakin biji direndam, maka semakin besar masuknya air ke dalam endosperma biji, sehingga memungkinkan benih berkecambah dengan cepat tetapi ada batasan tertentu untuk lamanya perendaman karena jika terlalu lama direndam maka biji akan mengalami pembusukan dan rusak (Sumanto dan Sriwahyuni, 1993).
Pada parameter yang telah dilakukan menunjukkan bahwa perendaman dengan waktu yang maksimal berbedanya nyata dengan perendaman dengan waktu yang minimum. Laju perkecambahan pada perlakuan dengan waktu yang maksimum sangat cepat dengan nilai rata-rata 3.22 hari, sedangkan pada perlakuan dengan waktu yang minimum dengan nilai rata-rata 5.56 hari.

\section{Presentase Kecambah Normal (\%)}

Hasil penelitian menunjukkan bahwa persentase perkecambahan normal tertinggi terdapat pada perlakuan P5 dan P7 sebesar $66.67 \%$. Lalu persentase perkecambahan terendah terdapat pada perlakuan P1 sebesar $33.33 \%$ (Tabel 2).

Tabel 2. Rataan Presentase Kecambah Normal (\%)

\begin{tabular}{cc}
\hline Perlakuan & $\begin{array}{c}\text { Presentase Kecambah } \\
\text { Normal }(\%)\end{array}$ \\
\hline P0 & 53.33 \\
P1 & 33.33 \\
P2 & 53.33 \\
P3 & 40.00 \\
P4 & 46.67 \\
P5 & 66.67 \\
P6 & 40.00 \\
\hline
\end{tabular}

Pada parameter uji daya kecambah normal menunjukkan nilai rata-rata tertinggi terdapat pada perlakuan dengan perendaman yang maksimum dengan nilai rata-rata $66.67 \%$, sedangkan pada perlakuan dengan waktu yang minimum dengan nilai rata-rata $33.33 \%$. Pada parameter uji daya kecambah abnormal menunjukkan nilai rata-rata tertinggi terdapat pada perlakuan P3, P4 dan P6 dengan nilai rata-rata $33.33 \%$, sedangkan pada perlakuan terendah terdapat pada perlakuan P0 sebesar $0.00 \%$. 


\section{Presentase Kecambah Abnnormal}

Hasil penelitian menunjukkan bahwa persentase perkecambahan abnormal tertinggi terdapat pada perlakuan P3, P4 dan P6 sebesar $33.33 \%$. Lalu persentase perkecambahan terendah terdapat pada perlakuan P0 sebesar $0.00 \%$ (Tabel 3).

Tabel 3. Presentase kecambah abnormal

\begin{tabular}{cc}
\hline Perlakuan & $\begin{array}{c}\text { Presentase Kecambah } \\
\text { Normal }(\%)\end{array}$ \\
\hline P0 & 0.00 \\
P1 & 13.33 \\
P2 & 6.67 \\
P3 & 33.33 \\
P4 & 33.33 \\
P5 & 13.33 \\
P6 & 33.33 \\
\hline
\end{tabular}

Kemunduran benih yang menyebabkan menurunnya vigor dan viabilitas benih merupakan awal kegagalan dalam kegiatan pertanian sehingga harus dicegah agar tidak mempengaruhi produktivitas tanaman. Menurut Sadjad (1972) kemunduran benih adalah mundurnya mutu fisiologis benih yang dapat menimbulkan perubahan menyeluruh di dalam benih, baik fisik, fisiologi maupun kimiawi yang mengakibatkan menurunnya viabilitas benih (Hartati et al., 1999).

Pada parameter benih mati menunjukkan nilai rata-rata tertinggi terdapat pada perlakuan $\mathrm{P} 1$ dengan nilai rata-rata sebesar $53.33 \%$, sedangkan yang terendah terdapat pada P4, P5 dan P7 dengan nilai rata-rata sebesar $20.00 \%$.

\section{SIMPULAN}

Laju perkecambahan tertinggi terdapat pada perlakuan P7 sebesar 3.22 hari. Hasil persentase perkecambahan normal tertinggi terdapat pada perlakuan
P5 dan P7 sebesar $66.67 \%$. Hasil persentase perkecambahan abnormal tertinggi terdapat pada perlakuan P3, P4 dan P6 sebesar $33.33 \%$.

\section{DAFTAR PUSTAKA}

Hasanah, M. 2002. Peran Mutu Fisiologik Benih dan Pengembangan Industri Benih Tanaman Industri. Jurnal Litbang Pertanian. 21(3) : 84 - 91.

Hartati, S., Sudjindro, F.C., Indriani. 1999. Pengaruh Invigorasi Terhadap Viabilitas Benih dan Pertumbuhan Tanaman Kenaf (Hibiscus Cannabinus L.). Jurnal Littri. 4(6):191 - 196.

Mardiah, A., Rahayu, R.W., Ashadi., Sawarni. 2009. Budi Daya dan Pengolahan Rosela Simerah Sigudang Manfaat. PT. Agromedia Pustaka, Bogor.

Sadjad, S.1994. Kuantifikasi Metabolisme Benih. PT Widia Sarana Indonesia, Jakarta.

Sutopo, L. 1998. Teknologi Benih. PT Raja Grafindo. Jakarta.

Sumarna, Y. 2008. Pengaruh Kondisi Kemasakan Benih dan Jenis Media Terhadap Pertumbuhan Semai Tanaman Penghasil Gaharu Jenis Karas (Aquilaria malaccensis Lamk.). Jurnal Penelitian Hutan dan Konservasi Alam. 4(2) : 129135. 